\title{
THE INFLUENCE OF INNOVATION FACTORS ON INNOVATION PERFORMANCE UNDER THE PERSPECTIVE OF INNOVATION VALUE CHAIN TAKE THE INDUSTRIES IN NORTHEAST CHINA AS EXAMPLES
}

\author{
Liu Hui \\ School of Economics of Liaoning University, Chongshan Middle Street, Liaoning, Shenyang \\ *Corresponding Author Email: 2370721740@qq.com
}

This is an open access article distributed under the Creative Commons Attribution License, which permits unrestricted use, distribution, and reproduction in any medium, provided the original work is properly cited.

\section{ARTICLE DETAILS}

\section{Article History:}

Received 12 March 2018 Accepted 12 April 2018 Available online 15 May 2018

\section{ABSTRACT}

This article divides the technological innovation process into three stages: product development, product transformation and product promotion from the perspective of the innovation value chain. Based on the data of manufacturing and high-tech industries in the three provinces of Northeast China from 2005 to 2015, using the panel regression method, the empirical study was conducted on the impact of innovation factors such as human capital, internal funds and external technologies on the innovation performance of various technological innovation processes.

\section{KEYWORDS}

Innovative elements, Innovation performance, Innovation value chain.

\section{INTRODUCTION}

In the high-speed competition era of economic globalization, the unique core competitive advantage of a region is the stable market and steady development. The technological innovation is the activity of developing and designing new products and new services and promoting them to the market by means of external support and internal resources, which is the decisive factor to build unique competitive advantages [1-3]. Changing innovation inputs to obtain better innovation performance is undoubtedly a key factor in the formation of a competitive advantage. Therefore, it is of great significance to analyze how different innovation elements affect the performance in different stages [4].

\section{THEORETICAL ANALYSIS AND LITERATURE REVIEW}

\subsection{Innovation Elements}

The innovation factor refers to the input resources of innovation activities that directly output Sci. \& Tech. achievements or the factors that influence the conditions for innovation support [5]. The input of it involves all aspects of the whole process of business operations such as R\&D, production, sales, management, and services. For the composition of innovative elements, it mainly includes three perspectives: system and environment perspectives, direct and indirect perspectives, and structural and functional perspectives [6]. Although the perspectives and content of the classifications are different, the essence of the classification is that it is mainly composed of talents, funds, and technology. Therefore, this paper mainly studies the impact of its talents, funds, and technology on innovation performance.

\subsection{Innovation Value Chain}

The innovation value chain was proposed by Hansen and Birkinshaw and they believed that the innovation value chain was divided into three stages: the creation of ideas, the conversion of ideas, and the dissemination of ideas [7]. Huang Gang and others believe that the innovation value chain refers to the realization process of innovation, including acquisition of innovation sources, transformation of innovation sources into new products and marketization [8]. Based on the above, this paper divides the technological innovation process into three stages: product development, product transformation, and product promotion.

\subsection{Research Overview}

In the existing related research, the research on the relationship between innovation factors and innovation performance mainly focuses on the following aspects. First, the research on Influencing Factors of innovation performance is mainly output oriented, such as the impact of R\&D input or expenditure and other inputs on innovation output. These studies only focus on one-way effects of a single factor or variable on innovation outcomes, but innovation is a multi-factor interaction process [9]. Second, from the perspective of measuring innovation performance, most studies are measured from the perspective of the enterprise, such as new product sales revenue, etc. Few studies measure the innovation performance from the perspective of social benefits, such as the benefits of industrial development, ecological improvement, and so on [10]. Finally, from the research scope, the research on input of innovation factors and performance mainly focuses on the level of industry. Few scholars analyze the relationship between innovation input factors and innovation performance from a regional perspective.

\section{RESEARCH HYPOTHESIS}

\subsection{Influence of Human Capital on Innovation Performance}

Human capital is an important determinant factor in determining technological innovation capabilities. The input of it mainly includes the number of Sci. \& Tech. personnel and the number of researchers. Many scholars have conducted related research, but the conclusions are different. Some empirical studies show that there is a significant positive correlation. However, some empirical studies have shown that there is no significant positive impact and even negative impact between the two factors. Based on this, this paper proposes the following hypotheses:

H1: Human capital has a positive impact on regional innovation performance.

H1a: The positive impact established during product development. 
H1b: The positive impact established during product transformation.

H1c: The positive impact established during product promotion.

\subsection{Influence of R\&D investment on innovation performance}

The level of regional R\&D input is an important factor affecting its independent innovation ability and determines its innovation performance and innovation competitive advantage. Most of the research has proved that the increase of $R \& D$ investment is beneficial to improving the ability of independent innovation and the level of innovation output [11]. Based on this, this paper proposes the following assumptions:

H2: Internal R\&D funds have a positive impact on innovation performance.

H2a: The positive impact established during product development.

$\boldsymbol{H} \mathbf{2 b}$ : The positive impact established during product transformation.

H2c: The positive impact established during product promotion.

\subsection{Influence of External Technology on Innovation Performance}

The external technology introduced by the region including foreign technology but not limited to it. But the degree of the matching of external technologies with theirs, the ability to digest technology may all directly lead to the effects of external technologies. Berchicci proved that it can improve the enterprise's innovation performance to a certain extent, but it will reduce it when it exceeds a certain threshold. Based on this, put forward the following assumptions:

H3: External technical has a negative impact on regional innovation performance.

H3a: The positive impact established during product development.

$\boldsymbol{H} \mathbf{3 b}$ : The positive impact established during product transformation.

$\boldsymbol{H} 3 \boldsymbol{c}$ : The positive impact established during product promotion.

\section{RESEARCH DESIGN}

\subsection{Data Collection and Processing}

The data in this paper is from the 2004-2015 < Statistics of Industrial Sci. \& Tech. Activities of Industrial Enterprises > and the 2005-2015 < Statistics Monitoring Results of National and Regional Sci. \& Tech. Progress $>$. Because there is a certain lag between the variables, this paper continues to lag for 1 year for performance. The variables are processed logarithmically to reduce the difference between the data and get the required comprehensive index through entropy method.

\subsection{Variable Measures}

\subsubsection{Innovative elements}

This study selected R\&D staff equivalent to full-time equivalent to measure the impact; internal funds are mainly measured through the internal R\&D spending of Sci. \& Tech. activities; external technologies are mainly reflected by expenditures for technology introduction expenditures, expenditures for technological transformation expenditures, funds for technology digestion and absorption expenses, and funds for the purchase of domestic technical expenditures.

\subsubsection{Innovation performance}

From the perspective of output, it is reflected both in the number of direct outputs and in the two major aspects of the benefits derived from the industrialization of Sci. \& Tech. and the positive effects on economic and social development. Therefore, this paper uses the number of patent applications and new product sales revenue to measure the innovation performance of the industry's $R \& D$ and conversion stages and uses the (high-tech) Sci. \& Tech. achievements industrialization index and science and technology to promote economic and social development index.

\section{EMPIRICAL ANALYSIS}

\subsection{Descriptive statistical analysis}

The results of descriptive statistical analysis of each variable, as shown in Table 1, show that the data is suitable for panel regression. Before estimating the models, four methods of LLC, IPS, Fisher_ADF and Fisher_PP were used for unit root test and it shown that each log series was stable.

Table 1: Descriptive statistics of major variables

\begin{tabular}{l|l|l|l|l|l|l|l}
\hline Variables & human & Internal fund & External tech & Patents & Sales & Promotion & Performance \\
\hline Mean & 10.19 & 13.45609 & 13.84512 & 7.736269 & 16.30350 & 3.798459 & 15.34046 \\
\hline Std. Dev. & 0.59 & 0.877118 & 0.667286 & 0.940168 & 0.781565 & 0.173191 & 0.781421 \\
\hline Kurtosis & 2.932151 & 2.337459 & 1.984272 & 2.229973 & 1.642541 & 4.417293 & 1.643121 \\
\hline Jarque-Bera & 3.634535 & 0.571609 & 1.956253 & 0.787000 & 2.309465 & 13.09560 & 2.307397 \\
\hline Probability & 0.162469 & 0.751409 & 0.376015 & 0.674691 & 0.315142 & 0.001433 & 0.315468 \\
\hline
\end{tabular}

\subsection{Panel Regression Results Analysis}

This paper uses human capital, internal R\&D funds, and external technical support as independent variables. Models 1, 2, 3, and 4 are constructed based on dependent variable of the number of patents, sales revenue of new products, promotion performance, and innovation performance. The regression results are shown in Table 2 . It can be seen that the P statistics of all models passed the significance test $(\mathrm{p}<0.05)$, indicating the correctness and feasibility of the models.

Table 2: Panel Regression Results for Innovation Performance

\begin{tabular}{|c|c|c|c|c|c|c|c|c|}
\hline MOdel & \multicolumn{2}{|l|}{ Model 1} & \multicolumn{2}{|l|}{ Model 2} & \multicolumn{2}{|l|}{ Model 3} & \multicolumn{2}{|l|}{ Model 4} \\
\hline Variables & Coefficient & Prob. & Coefficient & Prob. & Coefficient & Prob. & Coefficient & Prob. \\
\hline $\mathrm{C}$ & & & 21.78051 & 0 & 4.568721 & 0.0000 & 20.81465 & 0.0000 \\
\hline human & -0.487887 & 0.0054 & -1.017338 & 0.0058 & -0.463098 & 0.0000 & -1.017489 & 0.0058 \\
\hline Internal fund & 1.498426 & 0.0000 & 0.903283 & 0.0001 & 0.428338 & 0.0000 & 0.903673 & 0.0001 \\
\hline External tech & -0.538064 & 0.0000 & -0.524569 & 0.0164 & -0.131022 & 0.0021 & -0.524634 & 0.0164 \\
\hline
\end{tabular}

Model 1 examines the relationship between innovation factors and innovation performance during product development. It can be seen that there is a negative correlation between human capital and innovation performance in the Northeast China, so $\mathrm{H} 1 \mathrm{a}$ is not valid. The reason may be that the personnel in the three provinces are redundant and the utilization efficiency of human capital is relatively low. Therefore, as the R\&D personnel's increases, their performance decreases. There is a positive correlation between internal $R \& D$ funds and innovation performance, so $\mathrm{H} 2 \mathrm{a}$ is established. There is a negative correlation between external technical support and innovation performance.
Therefore, H3a is established.

Model 2 examines the relationship between them during product transformation. There is a negative correlation between regional human capital and innovation performance. Therefore, H1b does not hold. The reason may be that the utilization efficiency of regional human capital is relatively low. There is a positive correlation between internal R\&D funds and innovation performance, so $\mathrm{H} 2 \mathrm{~b}$ is established. There is a negative correlation between external technical support and innovation performance. With the increase of external technical support, the 
innovation performance decreases, so H3b is established.

Model 3 examines the relationship between them in the phase of product promotion. There is a negative correlation between human capital and innovation performance, so $\mathrm{H} 1 \mathrm{c}$ is not valid. The reason may be that the quality of regional R\&D staff is not studied in this paper. The quality of R\&D personnel (education, ability, etc.) may be relatively low or there is a big difference, then resulting in a negative correlation between them. There is a positive correlation between internal $\mathrm{R} \& \mathrm{D}$ funds and innovation performance, so $\mathrm{H} 2 \mathrm{c}$ is established. There is a negative correlation between external technical support and innovation performance, so $\mathrm{H} 3 \mathrm{c}$ is set up.

Model 4 examines the overall innovation performance and various innovation factors. The results are consistent with the test results of the above models. Human capital and external technologies have a negative correlation on innovation performance. Positive correlations are found between internal R\&D funds and innovation performance, so H1 is not established, H2, H3 is established.

\section{CONCLUSIONS AND RECOMMENDATIONS}

This article takes the manufacturing and high-tech industries of the Northeast as the research object and uses panel data from 2004 to 2015 as research samples to empirically analyze the impact of innovation factors on innovation performance in different stages of technological innovation. The main conclusions are as follows: From the direction of the impact, human capital and external technology have negative effects on all stages of innovation performance, while internal capital input has a positive impact on all stages of innovation performance.

According to the empirical analysis results, in order to further improve the innovation performance in the Northeast China, this paper proposes the following suggestions:

(1) Improve the efficiency and quality of R\&D personnel. First of all, the government should expand the channels for attracting talents, enhances the technical quality of R\&D personnel, and motivates R\&D personnel. Then, according to the actual conditions, optimize the allocation of various human capital and effectively solve the inefficiency of human capital investment in each province.

(2) Strengthen R\&D capital investment and focus on the efficiency of fund use.

(3) Pay attention to the matching of external technology and internal one and attach importance to internal R\&D before and after technology acquisition. Enterprises should rationalize the internal R\&D resource, attach importance to exploratory internal R\&D before acquiring external technologies, and pay attention to the development of internal R\&D after acquiring external technologies.

\section{REFERENCES}

[1] Los, B., Verspagen, B. 2000. R\&D spillovers and productivity: Evidence from U.S. manufacturing microdata [J]. Empirical Economics, 25 (1), 127 148

[2] Tsai, K.H. 2009. Collaborative networks and product innovation performance: toward a contingency perspective [J]. Research Policy, 38 (5), 765-778.

[3] Berchicci, L. 2013. Towards and open R\&D system: Internal R\&D investment, external knowledge acquisition and innovative performance [J]. Research Policy, (42), 117-127.

[4] Caviggioli, F. 2016. Technology fusion: Identification and analysis of the drivers of technology convergence using patent data [J]. Technovation, (55-56), 22-32.

[5] Hansenm, M.T., Birkinshaw, J. 2007. The Innovation Value Chain [J]. Harvard Business Review, 85 (6), 121-135.

[6] Zeng, S.X., Xie, X.M., Tam, C.M. 2010. Relationship between cooperation networks and innovation performance of SMEs [J]. Tec novation, 30 (3), 181-194.

[7] Scherer, F.M. 1965. Firm size, market structure, opportunity, and the output of patented inventions [J]. The American Economic Review, 55 (5), 1097-1125.

[8] Benhabib, J., Spiegel, M.M. 1994. The role of human capital in Economic development, evidence from aggregate cross-country data [J]. Journal of Monetary Economics, 34 (2), 143 -173.

[9] Islam, N. 1995. Growth empirics: a panel data approach [J]. Quarterly Journal of Economics, 110 (4), 1127-1170.

[10] Hurwitz, J., Lines, S., Montgomery, B., Schmidt, J. 2002. The linkage between management practices, intangibles performance and stock returns [J]. Journal of Intellectual Capital, 3 (1), 51 -61.

[11] Wang, C., Hu, Q. 2017. Knowledge sharing in supply chain networks: Effects of collaborative innovation activities and capability on innovation performance [J]. Technovation, In Press, Corrected Proof. 